\title{
The Correspondence between Emperor Leopold I and Johann Adolf of Schwarzenberg (1662-1683) Outline of an Edition Project
}

\author{
ROSTISLAV SMÍŠEK
}

In the last two decades, we could observe a growing interest of the historical research in the courts and personalities of the Habsburg emperors at the beginning of the Early Modern Age. ${ }^{1}$ There were some positivist works on individual members of the Habsburg family and the imperial court published in the second half of the nineteenth century and in the first half of the twentieth century. They followed traditional concepts of political, religious and particularly administrative history of the Danube Monarchy. ${ }^{2}$ These traditional methods were overcome in several comprehensive works by American, English, French and Austrian historians, written between the 1940s and 1980s. Some

See the review articles Václav Bůžen, Dvior habsburských císařu v letech 1526-1740 a historiografie na prahu 21. století, in: Václav Bůžek - Pavel Král (edd.), Šlechta v habsburské monarchii a císařský dvůr (1526-1741), České Budějovice 2003 (= Opera historica 10), pp. 5-32; Jeroen Duindam, Early Modern court studies: an overview and a proposal, in: Markus Völkel - Arno Strohmeyer (edd.), Historiographie an europäischen Höfen (16.-18. Jahrhundert). Studien zum Hof als Produktionsort von Geschichtsschreibung und historischer Repräsentation, Berlin 2009, pp. 37-60; Jakob WüHrER, Ein teilausgebautes Haus ohne Fundament? Zum Forschungsstand des frühneuzeitlichen Wiener Hofes am Beispiel der Organisationsgeschichte, Mitteilungen des Instituts für österreichische Geschichtsforschung 117,2009 , pp. 23-50. The study will be published with the financial support of Grantová agentura České republiky [The Czech Science Foundation], Nr. 19-16423S.

2 Eduard Vense, Geschichte des österreichischen Hofs und Adels und der österreichischen Diplomatie. Sektion II, Bd. I, Hamburg 1852 (= Geschichte der deutschen Höfe seit der Reformation 7); Heinrich Kretschmayr, Das deutsche Reichsvicekanzleramt, Archiv für österreichische Geschichte 84, 1898, pp. 381-502; Thomas Fellner - Heinrich Kretschmayr, Die Österreichische Zentralverwaltung. 1. Abteilung: Von Maximilian I. bis zur Vereinigung der österreichischen und böbmischen Hofkanzlei (1749) I-III, Wien 1907 (= Veröffentlichungen der Kommission für neuere Geschichte Österreichs 5-7); Ferdinand Мемс̌íк, Beiträge zur Geschichte der kaiserlichen Hofämter, Archiv für österreichische Geschichte 87, 1899, pp. 449-563; Ivan Žolger, Der Hofstaat des Hauses Österreich, Wien-Leipzig 1917; Lothar Gross, Die Geschichte der deutschen Reichshofkanzlei von 1559-1806, Wien 1933; Oswald von Gschliesser, Der Reichshofrat. Bedeutung und Verfassung, Schicksal und Besetzung einer obersten Reichsbehörde von 1559 bis 1806, Wien 1942 (= Veröffentlichungen der Kommission für neuere Geschichte Österreichs 33); IDEM, Das Beamtentum der hohen Reichsbehörden (Reichshofkanzlei, Reichskammergericht, Reichshofrat, Hofkriegrat), in: Günther Franz (ed.), Beamtentum und Pfarrerstand, Limburg 1972 (= Deutsche Führungsschichten in der Neuzeit 5), pp. 1-26; Oskar Regele, Der österreichische Hofkriegsrat 1556-1848, Wien 1949; Wolfgang Sellert (ed.), Die Ordnungen des Reichshofrates 1550-1766 I-II, Köln-Wien 1980-1990. 
of them made attempts to carry out a structural analysis of the society of the Habsburg Monarchy, or analyze integration processes at the level of particular countries as well as of the entire monarchy in the sixteenth and eighteenth century. Others chose to use the prosopograhical approach to the imperial court as the center of power. ${ }^{3}$ Other researchers, who were influenced by historical anthropology and by the history of mentalities, tried to penetrate the intellecutal world the Habsburgs and to describe their value systems. ${ }^{4}$ In the Central European milieu, they were followed up by Karl Vocelka and Lynne Heller. In their popular works they tried to look at the ruling family from the perspective of life cycles. They focused on possession, power, court ceremonial and representation. ${ }^{5}$

The modern systematic research in the courts of the Habsburg sovereigns started with Grete Klingestein's review essay on the monograph written by the American historian John Philip Spielman. In this book, he dealt with the accommodation facilities for the nobility in Vienna between 1600 and 1740 and with the relation between the court and the capital of the Habsburg empire. ${ }^{6}$ The review essay appeared in Zeitschrift für historische Forschung in $1995 .{ }^{7}$ In her critical essay, Grete Klingenstein regretted the absence of modern research methods in the historiography of the imperial court in Central Europe, in particular in Austrian historiography. She suggested that we need to respond to the newest methodological developments in the Westeuropean and American historiographies. At the end of her own review essay she provided a brief summary of the comtemporary research results and suggested some topics for a future historical research.

Henry F. Schwarz, The Imperial Privy Council in the Seventeenth Century, Cambridge 1943 (= Harvard Historical Studies 53); Victor S. Mamatey, The Rise of the Habsburg Empire 1526-1815, New York 1971; Jean BÉrenger, Finances et absolutisme autrichien dans la seconde moitié du XVII siècle, Paris 1975; IDEM, Histoire de l'Empire des Habsbourg, Paris 1990; Robert J. W. Evans, The Making of the Habsburg Monarchy 1550-1700. An Interpretation, Oxford 1979; Charles W. Ingrao, The Habsburg Monarchy 1618-1815, Cambridge 1994 (= New Approaches to European History 3).

4 Frances A. Yates, Astraea: The Imperial Theme in the Sixteenth Century, London-Boston 1975; Thomas DaCosta Kaufmann, Variations on the Imperial Theme in the Age of Maximilian II and Rudolf II, New York-London 1978; Karl Vocelka, Habsburgische Hochzeiten 1550-1600. Kulturgeschichtliche Studien zum manieristischen Repräsentationsfest, Wien-Köln-Graz 1976 (= Veröffentlichungen der Kommission für Neuere Geschichte Österreichs 65); IDEM, Die politische Propaganda Kaiser Rudolfs II., Wien 1981 (= Veröffentlichungen der Kommission für die Geschichte Österreichs 9); IDEM, Rudolf II. und seine Zeit, Wien 1985.

5 Karl Vocelka - Lynne Heller, Die Lebenswelt der Habsburger. Kultur- und Mentalitätsgeschichte einer Familie, Graz-Wien-Köln 1997; IDEM, Die private Welt der Habsburger. Leben und Altag einer Familie, Graz-Wien-Köln 1998.

6 John Philip Spielman, The City and the Crown. Vienna and the Imperial Court, 1600-1740, West Lafayette 1993.

7 Grete Klingenstein, Der Wiener Hof in der Frühen Neuzeit. Ein Forschungsdesiderat, Zeitschrift für historische Forschung 22, 1995, pp. 237-245. 
The research in Habsburg courts made further progress in terms of its institutionalisation, organisation and financial coverage when the research group Höfe des Hauses Österreich was established in the spring of 1999. The founders, who included Grete Klingenstein, Beatrix Bastl, Gernot Heiss, Stefan Sienell and Karl Vocelka, declared that the history of the imperial court requires an interdisciplinary approach to particular topics plus a better exchange of information about particular research projects. ${ }^{8}$

Thanks to these developments, in particular in the last two decades, modern conceptual and theoretical approaches of the American and Westeuropean historiography could be diffused in Central Europe. At this juncture, historiography in Central Europe progressed from purely descriptive works to more complex analyses of ideological content of fresco decorations, to the world of thoughts of their builders, to material culture of Habsburg residences and to enquiries about the functional meaning of these buildings. ${ }^{9}$ There have been even more topics of cultural history of the imperial family that have become the subject scholarly interest since then. First of all, there appeared richly documented books which sought to address the history of court theatre, music, opera or dance. ${ }^{10} \mathrm{~A}$ special attention has been paid to issues of the court representation,

8 For more about these workshops see Stefan Sienell, Arbeitskreis „Höfe des Hauses Österreich", Mitteilungen der Rezidenzen-Kommission der Akademie der Wissenschaften zu Göttingen 10, 2000, Nr. 2, pp. 27-28; Jan Paul Nieder korn - Stefan Sieneld, Arbeitskreis „Höfe des Hauses Österreich“, Frühneuzeit-Info 12, 2001, Nr. 2, pp. 7-9. The topics of particular workshops that were organised by this group since 1999, discussed and evaluated Václav BưžEK, Oblédnuti za pronimi péti workshopy pracovní skupiny Höfe des Hauses Österreich, Český časopis historický 100, 2002, pp. 202-204; IDEM, Dvưr habsburských cisařu, pp. 16-17, footnote 31.

$9 \quad$ See Franz Matsche, Die Kunst im Dienst der Staatsidee Kaiser Karls VI. Ikonographie, Ikonologie und Programmatik des „Kaiserstils" I-II, Berlin-New York 1981; IDEM, „Caesar et Imperium“. Die Fassadendekoration und das Deckenbild im Festsaal der ehemaligen Reichskanzlei in der Wiener Hofburg, Wien 2011; Friedrich Polleross, Tradition und Recreation. Die Residenzen der österreichischen Habsburger in der frühen Neuzeit (1490-1780), Majestas 6, 1998, pp. 91-148; Štěpán VÁcHA, Der Herrscher auf dem Sakralbild zur Zeit der Gegenreformation und des Barock. Eine ikonologische Untersuchung zur herrscherlichen Repräsentation Kaiser Ferdinands II. in Böhmen, Praha 2009; Herbert KARNER (ed.), Die Wiener Hofburg 1521-1705. Baugeschichte, Funktion und Etablierung als Kaiserresidenz, Wien 2014; Hellmut Lorenz - Anna Mader-Kratky (edd.), Die Wiener Hofburg 1705-1835. Die kaiserliche Residenz vom Barock bis zum Klassizismus, Wien 2016. In terms of methodology and concept more Michael Yonan, Interdisciplinary Material Culture Studies and the Problem of Habsburg-Lorraine Representation, in: Werner Telesko (ed.), Die Repräsentation der Habsburg-Lothringischen Dynastie in Musik, visuellen Medien und Architektur 1618-1918, Wien-Köln-Weimar 2017, pp. 21-37.

10 Franz Hadamowsкy, Barocktheater am Wiener Kaiserhof. Mit einem Spielplan (1625-1740), Wien 1955; Herbert Seifert, Die Oper am Wiener Kaiserhof im 17. Jahrbundert, Tutzing 1985; Maria Teresa Muraro (ed.), Lopera italiana a Vienna prima di Metastasio, Florenz 1990; Andrea Sommer-MAтнis, Die Tänzer am Wiener Hofe im Spiegel der Obersthofmeisteramtsakten und Hofparteienprotokolle bis 1740, Wien 1992; Michael RitTer, „Man sieht der Sternen König glantzen“. Der Kaiserhof im barocken Wien als Zentrum deutsch-italienischer Literaturbestrebungen (1653 bis 1818) am besonderen Beispiel der Libretto-Dichtung, Wien 1999; Elisabeth Hilscher, Mit Leier und Schwert. 
above all to festivities. ${ }^{11}$ It is also necessary to mention imperial (or royal) coronations, homages and festive entries of Habsburgs. ${ }^{12}$ Some researchers focused on life cycles of the members of the Habsburg family ${ }^{13}$ and on the court ceremonies. ${ }^{14}$ Works dealing with the construction of the image of the sovereign using different communicative means were still rather rare. ${ }^{15} \mathrm{~A}$ new research field has been discovered in the Habsburg

Die Habsburger und Musik, Graz-Wien-Köln 2000; Susanne Rode-Breymann, Musiktheater eines Kaiserpaars. Wien 1677 bis 1705, Hildesheim-Zürich-New York 2010; Andrea Sommer-Mathis Daniela Franke - Rudi Risatti (edd.), Spettacolo barocco! Triumph des Theaters, Petersberg 2016; W. Telesko (ed.), Die Repräsentation.

11 Richard Alewyn, Das große Welttheater. Die Epoche der höfischen Feste in Dokument und Deutung, Hamburg 1959; Andreas Gugler, Feste des Wiener Hofs von der Mitte des 15. bis zum Ende des 18. Jabrhunderts, Frühneuzeit-Info 11, 2000, Nr. 1, pp. 77-176; Kateřina Fajtlová - Miroslav KIndL (edd.), Koně v piškotech. Slavnosti na dvoře císaře Leopolda I., Olomouc 2017.

12 See Heinz Schomann, Kaiserkrönung. Wabl und Krönung in Frankfurt nach Bildern der Festbücher, Dortmund 1982; Štefan Holčíx, Korunovačné slávnosti 1563-1830, Bratislava 1986; Bernd Wanger, Kaiserwabl und Krönung in Frankfurt des 17. Jahrhunderts, Frankfurt am Main 1994; Benita Berning, „Nach altem löblichen Gebrauch“. Die böhmischen Königskrönungen der Frühen Neuzeit (1526-1723), Wien 2008; Jiř́i Kubeš, Trnitá cesta Leopolda I. za řimskou korunou (1657-1658). Volby a korunovace ve Svaté rî́si řimské v raném novověku, České Budějovice 2009; Jiří Hrbek, České barokni korunovace, Praha 2010; Štěpán VÁcha - Irena Veselá - Vít VlnAs - Petra VoKáčová, Karel VI. a Alžběta Kristýna. Česká korunovace 1723, Praha-Litomyšl 2009; Harriet RudolPH, Das Reich als Ereignis. Formen und Funktionen der Herrschaftsinszenierung bei Kaisereinzügen (15581618), Köln-Weimar-Wien 2011 (= Norm und Struktur 38); Mlada Holá, Holdovaci cesty českých panovníku do Vratislavi v pozdním středověku a raném novověku, Praha 2012; Géza PÁlffy - Ferenc Gábor Soltész - Csaba Tóth (edd.), Coronatus Posonii... Bratislavské korunovačné medaily a žetóny (1563-1830), Bratislava-Budapest 2014; Štefan Holčíx - Jana Luková - Zuzana Francová, Coronation Festivities/Krönungsfeierlichkeiten Bratislava/Preßburg 1563-1830, Bratislava 2015; Tünde Lengyelová - Géza Pálffy (edd.), Korunovácie a pohreby. Mocenské rituály a ceremónie v ranom novoveku, Budapest-Békéscsaba 2016.

13 Angela Stöckele, Taufzeremoniell und politische Patenschaften am Kaiserhof, Mitteilungen des Instituts fü österreichische Geschichtsforschung 90, 1982, pp. 271-337; Karl VocelKa, Habsburgische Hochzeiten 1550-1600. Kulturgeschichtliche Studien zum manieristischen Repräsentationsfest, Wien-Köln-Graz 1976; Herbert SEIfert, Der Sig-prangende Hochzeit-Gott. Hochzeitsfeste am Wiener Hof der Habsburger 1622-1699, Wien 1988; Magdalena Hawlik-van De Water, „Der schöne Tod." Zeremonialstrukturen des Wiener Hofes bei Tod und Begräbnis zwischen 1640 und 1740, Wien 1989; Andrea Sommer-Mathis, Tu felix Austria nube. Hochzeitsfeste der Habsburger im 18. Jahrbundert, Wien 1994; Václav Bůžex - Pavel Marek, Smrt Rudolfa II., Praha 2015.

14 Christina Hofmann, Das spanische Hofzeremoniell von 1500-1700, Frankfurt am Main-Bern-New York 1985; Irmgard Pangerl - Martin Scheutz - Thomas Win kelbauer (edd.), Der Wiener Hof im Spiegel der Zeremonialprotokolle (1652-1800). Eine Annäherung, Innsbruck-Wien-Bozen 2007; Maria Golubeva, Models of political competence: The evolution of political norms in the works of Burgundian and Habsburg court historians, c. 1470-1700, Leiden 2013.

15 Maria Goloubeva, The Glorification of Emperor Leopold I. in Image, Spectacle and Text, Mainz 2000; Rouven Pons, „Wo der gekrönte Löw hat seinen Kayser-Sitz“. Herrschaftsrepräsentation am Wiener Kaiserhof zur Zeit Leopolds I., Engelbach-Frankfurt am Main-München-New York 2001; Jutta 
emperors' image and their „second lives“ in historiography and literary fiction. ${ }^{16}$ Some of these research projects resulted in sophisticated modern biographies of the Holy Roman emperors at the beginning of the Modern Age. The new trends of modern historiography have made impact even on biographies of other male members of the House of Austria. ${ }^{17}$ However, wives and daughters of the members of the Habsburg family are a topic that is still neglected by European historians. Maria Theresia has been the only exception so far. ${ }^{18}$

Some historians have provided prosopographical and structural analyses of the imperial court and uncovered its social structures, the relationships inside this power institution, and the career models of early modern nobility. This type of research is based on an in-depth examination and evaluation of archival records that pertain to groups or provide lists of courtiers, such as court registers (Hofstaatsverzeichnisse), court calenders (Hofkalender) and ceremonial minutes (Zeremoniellprotokolle). ${ }^{19}$ The research still

Schumann, Die andere Sonne. Kaiserbild und Medienstrategien im Zeitalter Kaiser Leopolds I., Berlin 2003; Pierre BÉHar - Herbert Schneider (edd.), Der Fürst und sein Volk. Herrscherlob und Herrscherkritik in den habsburgischen Ländern der frühen Neuzeit, Röhring 2004.

16 Leopold R. G. Decloedt, Imago Imperatoris. Franz Joseph I. in der österreichischen Belletristik der Zwischenkriegszeit, Wien 1995; idem (ed.), An meine Völker. Die Literarisierung Franz Joseph I., Bern 1998; Martina Fuchs, Karl V.: eine populäre Figur? Zur Rezeption des Kaisers in deutschsprachiger Belletristik, Münster 2002.

17 Renate Schreiber, „Ein Galeria nach meinem Humor. “Erzherzog Leopold Wilhelm, Wien 2005; Thomas Brockmann, Dynastie, Kaiseramt und Konfession. Politik und Ordnungsvorstellungen Ferdinands II. im Dreißigjährigen Krieg, Paderborn-München-Wien-Zürich 2011; Mark Hengerer, Kaiser Ferdinand III. (1608-1657). Eine Biographie, Wien-Köln-Weimar 2012.

18 Katrin Keller, Erzherzogin Maria von Innerösterreich (1551-1608) zwischen Habsburg und Wittelsbach, Wien-Köln-Weimar 2012; Anne J. Cruz - Maria Galdi Stampino (edd.), Early Modern Habsburg Women. Transnational Contexts, Cultural Conflicts, Dynastic Continuities, Farnham-Burlington 2013; Bettina Braun - Katrin Keller - Matthias Schnettger (edd.), Nur die Frau des Kaisers? Kaiserinnen in der Frühen Neuzeit, Wien-Köln-Weimar 2016; Barbara Stollbe RG-RILINger, Maria Theresia: Die Kaiserin in ibrer Zeit. Eine Biographie, München 2017; Julia Hodapp, Habsburgerinnen und Konfessionalisierung im späten 16. Jahrhundert, Münster 2018.

19 Heinz Noflat scher, Räte und Herrscher. Politische Eliten an den Habsburger Höfen der österreichischen Länder 1480-1530, Mainz 1999; Stefan Sienell, Die Geheime Konferenz unter Kaiser Leopold I. Personelle Strukturen und Methoden zur politischen Entscheidungsfindung am Wiener Hof, Frankfurt am Main-Berlin-Bern-Bruxelles-New York-Oxford-Wien 2001 (= Beiträge zur Neueren Geschichte Österreichs 17); Andreas PečAr, Die Ökonomie der Ehre. Höfischer Adel am Kaiserhof Karls VI., Darmstadt 2003; Mark Hengerer, Kaiserhof und Adel in der Mitte des 17. Jahrhunderts. Eine Kommunikationsgeschichte der Macht in der Vormoderne, Konstanz 2004 (= Historische Kulturwissenschaft 3); Renate Zedinger, Migration und Karriere. Habsburgische Beamte in Brüssel und Wien im 18. Jahrhundert, Wien-Köln-Weimar 2004 (= Schriftenreihe der Österreichischen Gesellschaft zur Erforschung des 18. Jahrhunderts 9); Katrin Keller, Hofdamen. Amtsträgerinnen am Wiener Hofstaat des 17. Jahrhunderts, Wien-Köln-Weimar 2005; Hansdieter KörbL, Die Hofkammer und ihr ungetreuer Präsident. Eine Finanzbehörde zur Zeit Leopolds I., Wien 2009 
neglects the financial backround of the imperial court and the fiscal administration of the Habsburg Monarchy and its provinces. ${ }^{20}$ This research has reached its zenith in the comprehensive monographs by Thomas Winkelbauer and Karl Vocelka, which discuss the political, administrative and religious history of the Danube Monarchy and its provinces in the Early Modern Age. ${ }^{21}$ In Czech historiography, there has not appeared yet a work that would have applied such a modern approach to the history of the Habsburg Monarchy under the rule of the Habsburgs. The monograph Habsburkové 1526-1918 (The Habsburgs 1526-1918) has been the very first attempt to examine and evaluate the rule of the Habsburg dynasty in the Central European monarchy and its manifestation of power. It is a collective monograph in two volumes. Its authors showed the dynastic, cultural, religious, political and social history of the countries in Central Europe under the rule of the successors of Rudolf I from various angles. The main focus was on the detailed exposition of the family backround, daily life and representation of the members of the dynasty..$^{22}$

This monograph has applied modern methods of the research in the history of the imperial court and in the personalities of individual Habsburg sovereigns. This success has been possible only thanks to the work of some historians who had previously

(= Veröffentlichungen des Instituts für Österreichische Geschichtsforschung 54); Rostislav SMíšEK, Cisařský dvi̊r a dvorská kariéra Ditrichštejnu a Schwarzenberků za vlády Leopolda I., České Budějovice 2009 (= Monographia historica 11); Ivo Cerman, Habsburgischer Adel und Aufklärung. Bildungsverbalten des Wiener Hofadels im 18. Jahrbundert, Stuttgart 2010; Jiří Hr век, Barokni Valdštejnové v Čechách 1640-1740, Praha 2013; Petra VokáčovÁ, Př́běby o hrdé pokoře. Aristokracie českých zemi v době baroka, Praha 2014; Jiří Kubeš et alii, V zastoupeni císaře. Česká a moravská aristokracie v habsburské diplomacii 1640-1740, Praha 2018.

20 Peter Rauscher, Zwischen Ständen und Gläubigern. Die kaiserlichen Finanzen unter Ferdinand I. und Maximilian II. (1556-1576), Wien-München 2004 (= Veröffentlichungen des Instituts für Österreichische Geschichtsforschung 41); IDEM (ed.), Kriegführung und Staatsfinanzen. Die Habsburgermonarchie und das Heilige Römische Reich vom Dreißigjährigen Krieg bis zum Ende des habsburgischen Kaisertums 1740, Münster 2010; Peter Rauscher - Andrea Serles - Thomas WinKelbauer (edd.), Das „Blut des Staatskörpers“. Forschungen zur Finanzgeschichte der Frühen Neuzeit, München 2012; Jiří David, Nechtèné budováni státu. Politika, válka a finance na Moravě ve druhé polovinè 17. stoleti, Brno 2018; Stephan SAnder-Faes, Composite Domination and State Formation, 1650-1700: Manorialism and the Fiscal-Financial-Military Constitution in Habsburg Bohemia, Opera historica 19, 2018, pp. 151-190; IDEM, Staats-Desintegration in Praxis: Krieg, Kredit und Steuern in Böhmen unter Joseph I., Český časopis historický 117, 2019, pp. 36-58; William D. Godsey, The Sinews of Habsburg Power: Lower Austria in a Fiscal-Military State 1650-1820, Oxford 2018.

21 Karl Vocelka, Glanz und Untergang der höfischen Welt. Repräsentation, Reform und Reaktion im habsburgischen Vielvölkerstaat, Wien 2001; Thomas Winkelbauer, Ständefreiheit und Fürstenmacht. Länder und Untertanen des Hauses Habsburg im konfessionellen Zeitalter I-II, Wien 2003.

22 Václav BůžEx - Rostislav Smíš́s (edd.), Habsburkové 1526-1740. Země Koruny české ve středoevropské monarchii, Praha 2017; Ivo Cerman (ed.), Habsburkové 1740-1918. Vznikáni občanské společnosti, Praha 2016. 
published various court-related documents from the archives. ${ }^{23}$ These sources include ceremonial records and minutes, instructions for various court appointments ${ }^{24}$ or lists of members of the imperial court. ${ }^{25}$ Other historians have focused on ego-documents and self-narratives. Their common feature was the private character and psychologically complicated autobiographical significance. ${ }^{26}$ Some historians drew not only on ego-documents, private diaries and journals of the high-ranking court diginitaries ${ }^{27}$ and their private correspondence (Johann Josef Khevenhüller-Metsch, Raimond

23 Jeroen Duindam, Im Herzen der zusammengesetzten Habsburgermonarchie. Quellen zu einer neuen Geschichte des Hofes, der Regierung und der höfischen Repräsentation, in: Josef Pauser - Martin Scheutz - Thomas Winkelbauer (edd.), Quellenkunde der Habsburgermonarchie (16.-18. Jahrhundert). Ein exemplarisches Handbuch, Wien-München 2004 (= Mitteilungen des Instituts für Österreichische Geschichtsforschung. Ergänzungband 44), pp. 21-32.

24 Jakob WüHrer - Martin Scheutz (edd.), „Zu Diensten Ihrer Majestät. “ Hofordnungen und Instruktionsbücher am frühneuzeitlichen Wiener Hof, Wien-München 2011 (= Quelleneditionen des Instituts für Österreichische Geschichtsforschung 6); Anita Hipfinger - Josef Löffler - Jan Paul Nieder korn - Martin Scheutz - Thomas Win kelbauer - Jakob WüHrer (edd.), Ordnung durch Tinte und Feder? Genese und Wirkung von Instruktionen im zeitlichen Längsschnitt vom Mittelalter bis zum 20. Jahrhundert, Wien-München 2012 (= Veröffentlichungen des Instituts für Österreichische Geschichtsforschung 60).

25 Jaroslava Hausenblasová, Der Hof Kaiser Rudolfs II. Eine Editition der Hofstaatsverzeichnisse 1576-1612, Praha 2002 (= Fontes historiae artium 9); Irene Kubiska-Scharl - Michael Pölz, Die Karrieren des Wiener Hofpersonals 1711-1765. Eine Darstellung anhand der Hofkalender und Hofparteienprotokolle, Innsbruck-Wien-Bozen 2013, and database of the staff at the court of Leopold I in the scope of the project Die Wiener Hofgesellschaft während der Regierungszeit Kaiser Leopolds I. http://www.oesta.gv.at/site/6662/default.aspx.

26 Harald Tersch, Österreichische Selbstzeugnisse des Spätmittelalters und der Frühen Neuzeit (1400-1650). Eine Darstellung in Einzelbeiträgen, Wien-Köln-Weimar 1998, pp. 11-13; IDEM, Die Beschäftigung mit dem Ich, in: Karl Vocelka - Rudolf Leeb - Andrea Scheichl (edd.), Renaissance und Reformation. Oberösterreichische Landesausstellung 2010, Linz 2010, pp. 129-134; Harald Tersch - Martin Scheutz, Selbstzeugnisse der Frühen Neuzeit. Der lange Weg der schriftlichen Selbstvergewisserung, in: Peter Eigner - Christa Hämmerle - Günter Müller (edd.), Briefe - Tagebücher - Autobiographien. Studien und Quellen für den Unterricht, Innsbruck-Wien-Bozen 2006 (= Konzepte und Kontroversen 4), pp. 10-27.

27 Rudolf Khevenhüller-Metsch - Hanns Schlitter (edd.), Aus der Zeit Maria Theresias. Tagebuch des Fürsten Johann Josef Khevenhüller-Metsch, kaiserlichen Obersthofmeisters 1742-1776 I-VII, Wien 1907-1925; Marie Koldinská - Petr MAŤa (edd.), Deník rudolfinského dvořana. Adam mladši z Valdštejna 1602-1633, Praha 1997; Maria Breunlich - Marieluise Mader (edd.), Karl Graf von Zinzendorf. Aus den Jugendtagebüchern 1747, 1752 bis 1763. Nach Vorarbeiten von Hans Wagner, Wien-Köln-Weimar 1997; Grete Klingenstein - Eva Faber - Antonio Trampus (edd.), Europäische Aufklärung zwischen Wien und Triest. Die Tagebücher des Gouverneurs Karl Graf von Zinzendorf 1776-1782 I-IV, Wien-Köln-Weimar 2009; Rostislav Sмíšeк (ed.), Das Tagebuch Ferdinands zu Schwarzenberg aus den Jahren 1686-1688 und 1696-1697. Eine vollständige kritische Edition, České Budějovice 2015 (= Prameny k českým dějinám 16.-18. století, řada B, svazek 5). Cf. Petr MAт̌A, Tagebücher, in: J. Pauser - M. Scheutz - T. Winkelbauer (edd.), Quellenkunde der Habsburgermonarchie, pp. 767-780. 
Montecuccoli, Zdenko Adalbert Popel of Lobkowicz, Ferdinand of Schwarzenberg, Adam Jr. of Waldstein, Charles of Zinzendorf), ${ }^{28}$ but also on individuals who were closely linked to the court milieu (e.g. Ernst Adalbert of Harrach) ${ }^{29}$ and on the correspondence and diaries of the Habsburg emperors Ferdinand I, ${ }^{30}$ Maximilian II, ${ }^{31}$ Ferdinand II, ${ }^{32}$ Charles VI ${ }^{33}$ or Maria Theresa. ${ }^{34}$

A special case are the 35000 handwritten letters of Emperor Leopold I. He sent them to various recipients during his long life. When it comes to the regular recipients of his private letters, these were in no way randomly chosen individuals, but a carefully

28 Alois Veltzé (ed.), Ausgewaehlte Schriften des Raimund Fürsten Montecuccoli I-IV, Wien 1899-1900; Pavel Marek (ed.), Svédectvi o ztrátè starého svèta. Manželská korespondence Zdeňka Vojtècha Popela z Lobkovic a Polyxeny Lobkovické z Pernštejna, České Budějovice 2005 (= Prameny k českým dějinám 16.-18. století, řada $\mathrm{B}$, svazek 1 ).

29 Katrin Keller - Alessandro Catalano (edd.), Die Diarien und Tagzettel des Kardinals Ernst Adalbert von Harrach (1598-1667) I-VII, Wien-Köln-Weimar 2010 (= Veröffentlichungen der Kommission für Neuere Geschichte Österreichs 104/I-VII).

30 Wilhelm Bauer (ed.), Die Korrespondenz Ferdinands I. Bd. I: Familienkorrespondenz bis 1526, Wien 1912; Wilhelm Baue r - Robert Lacroix (edd.), Die Korrespondenz Ferdinands I. Bd. II/1-2: 1. Hälfte: Familienkorrespondenz 1527 und 1528, 2. Hälfte: Familienkorrespondenz 1529 und 1530, Wien 1937-1938; Herwig Wolf ram - Christine Thomas (edd.), Die Korrespondenz Ferdinands I. Bd. III: Familienkorrespondenz 1531 und 1532, Wien 1973; Christopher F. LAFERL - Christina Lutter (edd.), Die Korrespondenz Ferdinands I. Bd. IV: Familienkorrespondenz 1533 und 1534, WienKöln-Weimar 2000; Bernadette Hofinger - Harald Kufner - Christopher F. Laferl - Judith Moser-Kroiss - Nicola Tschugmell (edd.), Die Korrespondenz Ferdinands I. Bd. V: Familienkorrespondenz 1535 und 1536, Wien-Köln-Weimar 2015.

31 Viktor Bibl (ed.), Die Korrespondenz Maximilians II. Bd. I: Familienkorrespondenz 1564 Juli 26 1566 August 11, Wien 1916; IDEM (ed.), Die Korrespondenz Maximilians II. Bd. II: Familienkorrespondenz 1566 August 9 - 1567 Dezember 27, Wien 1921; Arno St rohmayer (ed.), Der Briefwechsel zwischen Ferdinand I., Maximilian II. und Adam von Dietrichstein 1563-1565, Wien-München 1997.

32 Beda DuDí (ed.), Correspondenz Kaisers Ferdinand II. und seiner erlauchten Familie mit P. Martinus Becanus und P. Wilhelm Lamormaini, kaiserlichen Beichtvätern S. J., Archiv für österreichische Geschichte 54, 1876, pp. 219-350.

33 Alfred von Arneth, Eigenhändige Korrespondenz des Königs Karl III. von Spanien (nachmals Kaiser Karl VI.) mit dem Obersten Kanzler des Königreichs Böhmen Grafen Johann Wenzel Wratislaw, Wien 1856; Stefan Seiтscheк, Die Tagebücher Kaiser Karls VI. Zwischen Arbeitseifer und Melancholie, Horn 2018.

34 See Alfred von Arneth (ed.), Maria Theresia und Marie Antoinette. Ibr Briefwechsel, Leipzig 1866; IDEM (ed.), Maria Theresia und Joseph II. Ihre Correspondenz sammt Briefen Joseph's an seinen Bruder Leopold I-III, Wien 1867-1868; IDEM (ed.), Briefe der Kaiserin Maria Theresia an ibre Kinder und Freunde I-IV, Wien 1881; Carl Rothe (ed.), Die Mutter und die Kaiserin. Briefe der Maria Theresia an ibre Kinder und Vertraute, München 1968; Friedrich Walter (ed.), Maria Theresia. Briefe und Aktenstücke in Auswahl, Darmstadt 1968 (= Ausgewählte Quellen zur deutschen Geschichte der Neuzeit 12); Severin Perrig (ed.), „Aus mütterlicher Woblmeinung“: Kaiserin Maria Theresia und ibre Kinder. Eine Korrespondenz, Weimar 1998; Monika Czerninová - Jean-Pierre Lavandier (edd.), Mějte mě stále ráda. Marie Terezie: dopisy nejbližši prútelkyni, Praha 2018. 
selected group of thirty people. All of them belonged to his key collaborators in different fields of Habsburg policy. ${ }^{35}$ The circle of people to whom the letters of Leopold I were addressed, can be divided into four basic groups. The first group included the family members and relatives, plus high-ranking court dignitaries and representatives of the central administrative authorities of the Danube Monarchy (Ferdinand Josef of Dietrichstein, Franz Ulrich Kinský, Wenzel Euseb of Lobkowicz, Johann Adolf of Schwarzenberg). The members of the second group were imperial ambassadors and diplomats to the different European countries (Ferdinand Bonaventura of Harrach, Humprecht Johann Czernin of Chudenice, Wenzel Ferdinand of Lobkowicz, Franz Eusebius of Pötting), the third group included high-ranking court officials in the individual parts of the Habsburg Monarchy (Humprecht Johann Czernin of Chudenice, Bernard Ignatz of Martinic, Adolf Wratislaw of Sternberg). The members of the last group were spiritual advisors and powerful dignitaries of the Catholic Church (Marco d'Aviano, Hippolito da Pergine, Emmerich Sinelli, Johann Charles Joachim of Slavata). ${ }^{36}$

However, modern editions of documents have made accessible only a tiny percentage of these letters (approximately 820 letters). What makes his letters difficult to publish is their extraordinary linguistic diversity and bad legibility, which had triggered some complaints even from the contemporaries of Emperor Leopold I. The editions that have been published so far include the Emperor's correspondence with the Capuchin monk Marco d'Aviano, then with Wenzel Eusebius of Lobkowicz, the Master of the Court, then with the imperial ambassador to Madrid Franz Eusebius of Pötting, then with the imperial ambassador to Venice Humprecht Johann Czernin of Chudenice and lastly with the Bishop of Vienna Emmerich Sinelli. ${ }^{37}$

35 Petr Maťa - Stefan Sienell, Die Privatkorrespondenzen Kaiser Leopolds I., in: J. Pauser M. Scheutz - T. Winkelbauer (edd.), Quellenkunde, pp. 837-848. See Theodor von Heigel, Neue Beitrage zur Charakteristik Kaiser Leopolds I, Sitzungsberichte der philosophisch-philologischen und historischen Classe der k. b. Akademie der Wissenschaften zu München 1890, Nr. 2, pp. 109-147.

36 Petr MAŤA, Leopold I. a posledni Slavata. Kosobni korespondenci panovníkủ ranébo novovéku, in: Ivan Hlaváček - Jan Hrdina - Jan Kahuda - Eva Doležalová (edd.), Facta probant homines. Sborník příspěvků k životnímu jubileu Prof. Dr. Zdeňky Hledíkové, Praha 1998, pp. 245-257, here pp. 250-251; P. Maťa - S. Sienell, Die Privatkorrespondenzen, pp. 839-840.

37 Onno Klopp (ed.), Corrispondenza epistolare tra Leopoldo I. imperatore ed il P. Marco d'Aviano capuccino, Graz 1888; Max Dvořáк (ed.), Briefe Kaiser Leopold I. an Wenzel Euseb Herzog in Schlesien zu Sagan, Fürsten von Lobkowitz 1657-1674, Wien 1894; Alfred Francis Pribram - Moriz Landwehr von Pragenau (edd.), Privatbriefe Kaiser Leopold I. an den Grafen F. E. Pötting 1662-1674 I-II, Wien 1903-1904; Zdeněk Kalista (ed.), Korespondence císaře Leopolda I. s Humprechtem Janem Černinem z Chudenic. Díl I. (Duben 1660 - zárí 1663), Praha 1936; Marie HÉYret, P. Marcus von Aviano O. M. Cap. (1631-1699). Sein Briefwechsel nach dem Hauptinhalt und den geschichtlichen Zusammenhängen. Bd. 2: Der Römisch-deutsche Kaiser Leopold I. und P. Marcus (1680-1699). Nach dem Original-Handschriften, München 1938; Helga Kirchberger (ed.), Briefe Leopolds I. an P. Emerich Sinelli 1668-1675, Wien 1953 (Dissertation); Arturo M. da Carmignani di Brenta (ed.), P. Marco d'Aviano. Corrispondenza Epistolare II, Abano Terme 1987. 
Only few Czech or foreign historians have used the private correspondence between Leopold I and Johann Adolf of Schwarzenberg which is deposited in Státní oblastní archiv [State Regional Archives] Třeboň, oddělení [Satellite Office] Český Krumlov. ${ }^{38}$ The letters date from 1662 to 1683 . Although this set of handwritten documents is wellknown to the expert community, it has not been adequately appreciated yet. In the early nineteenth century, the Schwarzenberg archivists Adolf Franz Berger, Anton Mörath and Theodor Wagner made historians already aware of the surviving letters. ${ }^{39}$ Petr Mata and Stefan Sienell mentioned these handwritten documents in their articles about the private correspondence of Emperor Leopold I and Johann Charles Joachim of Slavata. ${ }^{40}$ The only historian who analyzed the content of the correspondence between Leopold I and Johann Adolf of Schwarzenberg was Rostislav Smíšek. It was in his investigation of the career strategies of the Princes of Schwarzenberg in the seventeenth and at the beginning of the eighteenth century. ${ }^{41}$

The main result of the project will be a critical edition of handwritten letters between Leopold I and Johann Adolf of Schwarzenberg from 1662 to $1683 .{ }^{42}$ The Franconia-origin nobleman was born on September 20,1615. ${ }^{43} \mathrm{He}$ started his public activities in the Order of the Knights of Malta. However, from 1640 onwards, he took an active

38 Státní oblastní archiv [State Regional Archives] Třeboň, oddělení [Satellite Office] Český Krumlov, Rodinný archiv Schwarzenberků [Schwarzenberg Family Archives], file 366.

39 Theodor Wagner, Zum Charactergemälde des Fürsten Johann Adolf zu Schwarzenberg, Präsidenten des kaiserl. Reichshofrathes u. s. w., Wittingau 1852 (Státní oblastní archiv [State Regional Archives] Třeboň, oddělení [Satellite Office] Ceský Krumlov, Sbírka rukopisů Český Krumlov [The Manuscript Collection of Český Krumlov] 1327-1968, Nr. 80); Adolph Franz Berger, Felix Fürst zu Schwarzenberg, k. k. Ministerpräsident. Ein Biographisches Denkmal, Berlin 1853, pp. 116-117; Anton Mörath, Archivalien des fürstlich schwarzenberg'schen Zentralarchivs in Krumau für die neuere Geschichte Österreichs, in: Archivalien zur neueren Geschichte Österreichs I, Wien 1913, pp. 12-27, here p. 19.

40 P. MaŤA, Leopold I. a posledni Slavata, p. 255; P. MAŤA - S. Sienell, Die Privatkorrespondenzen, pp. 840,846 .

${ }_{41}$ Rostislav SмíšsK, Cisařšký dvưr a dvorská kariéra; IDEM, Johann Adolf et Ferdinand, deux carrières de courtisan, in: Olivier Chaline - Ivo Cerman (edd.), Les Schwarzenberg. Une famille dans l'histoire de l'Europe XVI ${ }^{\mathrm{e}}-\mathrm{XXI}{ }^{\mathrm{e}}$ siècles, Paris 2012, pp. 65-79; IDEM, Die Schwarzenberger und ibr Weg an den Kaiserhof im 17. und zu Beginn des 18. Jabrbunderts, in: Anna Fundárková - István Fazekas (edd.), Die weltliche und kirchliche Elite aus dem Königreich Böhmen und Königreich Ungarn am Wiener Kaiserhof im 16.-17. Jahrhundert, Wien 2013, pp. 441-468.

42 Cf. Stefan Sienell, Editionsvorbaben: I. Briefe Kaiser Leopolds I. an Johann Ferdinand von Portia (1657-1665); II. ,Verzeichnis der Sitzungen der Geheimen Konferenz unter Kaiser Leopold I. ", in: Grete Klingenstein - Fritz Fellner - Hans Peter Hye (edd.), Umgang mit Quellen heute. Zur Problematik neuzeitlicher Quelleneditionen vom 16. Jahrhundert bis zur Gegenwart, Wien 2003, pp. 70-73, 239-241.

43 H. F. Schwarz, The Imperial Privy Council, pp. 336-340; K. zu Schwarzenberg, Geschichte, pp. 116-127; S. Sienell, Die Geheime Konferenz, pp. 85-87. 
part at the sessions of the Imperial Aulic Council as an imperial advisor and councillor. Five years later he entered the service of Archduke Leopold William of Austria, the brother of Ferdinand III and the Governor of Spanish Netherlands. Later on, he held the office of the High Chamberlain (Oberstkämmerer), the Master of the Horse (Oberststallmeister) and the High Steward of the Court (Obersthofmarschall). ${ }^{44}$ In 1650, he received the Order of the Golden Fleece from the King of Spain Philip IV. ${ }^{45}$ After the return of Leopold William to Vienna he began to attend regularly the sessions of the Privy Council and the Privy Conference - the advisory bodies to the Emperor on issues related to home affairs and foreign policy of the Habsburg Monarchy. ${ }^{46}$ After the death of Leopold William in 1662 he entered the service of Emperor Leopold I. The Emperor appointed Count of Schwarzenberg to the position of the President of the Imperial Aulic Council on November 28, 1670. At the same time, he was received the princely title. ${ }^{47}$ Although he tried to gain one of the court offices for himself, in particular the office of the Emperor's Master of the Court, he never suceeded. On May 26, 1683, he died in Laxenburg. ${ }^{48}$

Altogether 150 handwritten letters ${ }^{49}$ of the Emperor, in German, that were addressed to Johann Adolf of Schwarzenberg come from this particular period when

44 Cf. letter from Leopold William to Emperor Ferdinand III. from September 20, 1645. Státní oblastní archiv [State Regional Archives] Třeboň, oddělení [Satellite Office] Český Krumlov, Rodinný archiv Schwarzenberků [Schwarzenberg Family Archives], file. 355. H. F. Schwarz, The Imperial Privy Council, p. 337; K. zu Schwarzenberg, Geschichte, p. 118.

45 The bestowal document from August 1,1650 is deposited in Státní oblastní archiv [State Regional Archives] Třeboň, oddělení [Satellite Office] Český Krumlov, Rodinný archiv Schwarzenberků [Schwarzenberg Family Archives], file 355. Cf. František Loвкоwicz, Zlaté rouno v Čechách, Praha 1991 (= Heraldika a genealogie. Supplementum 24), p. 276; Kristýna Bauerová, „Ad maiorem gentis gloriam “. Jan Adolf ze Schwarzenberku a Řád zlatébo rouna, in: Kateřina Kovárová - Zbyněk Sviták (edd.), Historie 2015/2016. Sborník prací z celostátní studentské vědecké konference Brno 21.-22. dubna 2016, Brno 2017, pp. 43-69.

46 R. Schreiber, „Ein Galeria nach meinem Humor“, pp. 39-40, 44, 74; Jean Bérenger, Deník Jana Adolfa ze Schwarzenberku, in: Václav Bůžek (ed.), Slechta raného novověku pohledem českých, francouzských a španělských historiků, České Budějovice 2009 (= Opera historica 13), pp. 41-57; Rostislav Sмíš́к, Císařský dvĩr v polovině 17. stoleti očima nejvyššího hofmistra arciknízete Leopolda Viléma. Deník Jana Adolfa ze Schwarzenberku z roku 1657, Folia historica bohemica 27, 2012, pp. 263-314.

47 A. F. Pribram - M. Landwehr von Pragenau (edd.), Privatbriefe II, pp. 173-174; H. F. Schwarz, The Imperial Privy Council, p. 339; K. zu Schwarzenberg, Geschichte, pp. 122-123.

48 More the dispatches of the papal nuncio in Vienna Francesco Buonvisi from May 30, and June 6, 1683. Archivio Segreto Vaticano, Segretario di Stato - Germania, sign. 207, fol. 394, 400-401, 414-415. Christian Beese, Markgraf Hermann von Baden (1628-1691). General, Diplomat und Minister Kaiser Leopolds I., Stuttgart 1991, p. 221.

49 It is very difficult to specify the precise number of letters written by Leopold I to Johann Adolf of Schwarzenberg. Apart from the 150 letters in Státní oblastní archiv [State Regional Archives] 
he served Emperor Leopold I. The surviving items represent quite a large file of letters written by Leopold I. ${ }^{50}$ The means of expression and literal messages in the letters imply that this is only a small percentage of the original number of letters. The lentgh of particular letters varies from short messages (Biletten), just a few lines long, to two-page letters. The informative value of the correspondence is extraordinarily interesting, as it reflects the gradual changes of the relationship between the Emperor and Schwarzenberg, who was an extremely disliked servant in the beginning. The initial distrust of the young sovereign originated from the fact that Johann Adolf of Schwarzenberg responded calmly to the news that Leopold I was elected Emperor in 1657-1658. He pursued his own power interests and promoted the claims of Archduke Leopold William to the imperial throne. ${ }^{51}$ However, he gained Emperor's trust and acknowledgement over time (this conclusion has been substantiated by the words of encouragement Leopold I used to assure Johann Adolf of Schwarzenberg of his grace and the expressions of concern related to his health as well). ${ }^{52}$ The intellectual world of the Emperor will be a special focus of the edition. From time to time, these letters provide valuable insights into his personal opinions, emotions and feelings concerning his health, his choice of bride, the family, the court members, the members of the officers' corps of the imperial army and the daily routines of the court in Vienna. ${ }^{53}$

Třeboň, oddělení [Satellite Office] Český Krumlov, Rodinný archiv Schwarzenberků [Schwarzenberg Family Archives], file 366, there are various scattered letters from the emperor in the Rodinný archiv Schwarzenberků [Schwarzenberg Family Archive]. More about the handwritten letter written by Leopold I to Johann Adolf of Schwarzenberg from July 15, 1657. IвіDем, file 374.

50 In most of the cases these are Emperor's autographs. The handwriting of Emepror Leopold I was very often difficult to read even for the recipients of his letters. Therefore, they would advise their secretaries and other servants to rewrite the letters sp that they could be better understood. In doing so, they would sometimes try to figure out what Leopold I meant. In these cases, they would often misread them. They followed rather the meaning of the sentences and the context in their transcriptions. Johann Adolf of Schwarzenberg used the same method. This can be proved by the twenty letters that are deposited ıвıдем, file 366. Cf. P. MAт̌A, Leopold I. a posledni Slavata, p. 245; R. Sмíšeк, Císařský dvưr a dvorská kariéra, pp. 434-435, footnote 1633.

51 Adam Wolf, Fürst Wenzel Lobkowitz, erster geheimer Rath Kaiser Leopold's I. 1609-1677. Sein Leben und Wirken, Wien 1869, pp. 78-104; H. F. Schwarz, The Imperial Privy Council, pp. 338-339; R. Schreiber, „Ein Galeria nach meinem Humor“, pp. 44-45; R. Smíšex, Císařský dvür a dvorská kariéra, pp. 110-114.

52 For more about the issue see the letters from Leopold I to Johann Adolf of Schwarzenberg from August 21,1669, June 19 and 26, 1673 or April 30,1683. Státní oblastní archiv [State Regional Archives] Třeboň, oddělení [Satellite Office] Český Krumlov, Rodinný archiv Schwarzenberků [Schwarzenberg Family Archives], file 366, fol. 38-39, 56, 83-84, 170-171; R. Sмíšsk, Císařský dvưr a dvorská kariéra, pp. 114-115.

53 P. Maťa, Leopold I. a poslední Slavata; P. MAŤa - S. Sienell, Die Privatkorrespondenzen; R. SmíšEk, Císařský dvưr a dvorská kariéra, pp. 434-443. 
The correspondence discusses also quite frequently the Emperor's reflections on the activities of his advisory bodies - the Privy Council and Privy Conference. Johann Adolf of Schwarzenberg was one of their powerful members. Many letters reflect the structure of decision-making processes that was carried out by these advisory bodies. They pertain also to the opinions of Emperor Leopold I and Johann Adolf of Schwarzenberg regarding the appointments to particular offices, central administrative authorities, the relationship between the particular administrative bodies and particular noblemen and individuals of low birth. ${ }^{54}$ The letters tackle also the case of Emperor's Chief Master of the Court Wenzel Eusebius of Lobkowicz and the circumstances of his political downfall in 1674. Prince of Schwarzenberg belonged to the members of the board of investigation. ${ }^{55}$ The letters provide also sufficient basis for an analysis of the relations of the Habsburg Monarchy and the Emperor to particular European countries - Spain, France, Polish-Lithuanian Union, Ottoman Empire, the Netherlands, the countries on the Apennine Peninsula, particular territories of the Holy Roman Empire and Habsburg Monarchy, in particular to Hungary. ${ }^{56}$

The main output of the project will be a critical edition of the private correspondence of Leopold I addressed to Johann Adolf of Schwarzenberg between 1662 and 1683. To meet the high standards of a critical edition the work has to meet certain standards. The edition will be prefaced by a comprehensive introductory study. It will sum up the current state of research in the career and life of Johann Adolf of Schwarzenberg. Apart from that it will draw on previous archival research to shed more light on the personality of this nobleman so that we can identify his place within a broader network of social relations of the second half of the seventeenth century. The main focus will be placed on the content analysis of the correspondence under research. The correspondence can not be investigated as an isolated document, therefore it has to be regarded in the context of other preserved letters of Leopold I. As Petr Mata put it, each set of letters allows us to look inside particular areas of Leopold's interests and at the same time each of them

54 Cf. Stefan Sienell, Die Ersten Minister Kaiser Leopolds I.: Johann Ferdinand von Portia und Wenzel Eusebius von Lobkowitz, in: Michael Kaiser - Andreas Pečar (edd.), Der zweite Mann im Staat. Oberste Amtsträger und Favoriten im Umkreis der Reichsfürsten in der Frühen Neuzeit, Berlin 2003, pp. 317-330.

55 More about it Státní oblastní archiv [State Regional Archives] Třeboň, oddělení [Satellite Office] Český Krumlov, Rodinný archiv Schwarzenberků [Schwarzenberg Family Archives], file 365;

A. Wolf, Fürst Wenzel Lobkowitz, pp. 405-426; J. Bérenger, Denik Jana Adolfa ze Schwarzenberku, pp. 52-53.

56 John Philip Spielman, Leopold I. Zur Macht nicht geboren, Graz-Wien-Köln 1981; Jiří Mikulec, Leopold I. Život a vláda barokního Habsburka, Praha-Litomyšl 1997; Jeroen Duindam, Vienna and Versailles. The Courts of Europe's Dynastic Rivals, 1550-1780, Cambridge 2003; Jean BÉrenger, Léopold I Ir (1640-1705) fondateur de la puissance autrichienne, Paris 2004; José Martínez Millán Rubén Gonzáles Cuerva (ed.), La Dinastía de los Austria. Las relaciones entre la Monarquía Católica y el Imperio I-II, Madrid 2011. 
shows his specific relation to their recipients. ${ }^{57}$ For this reason, it will be necessary to investigate also other unpublished pieces of the private correspondence of Leopold I that are deposited in Czech and Austrian archives and libraries, in particular the correspondence with high-ranking court dignitaries, and the representatives of the central administrative authorities of the Habsburg Monarchy as for example Ferdinand Josef of Dietrichstein, Johann Maximilian of Lamberg, Wenzel Eusebius of Lobkowicz. ${ }^{58}$ We will also investigate selected correspondence of high-ranging court dignitaries and dispatches of the foreign ambassadors at the court in Vienna. ${ }^{59}$ This particular area of research will help us to reconstruct the image of the Prince of Schwarzenberg in the eyes of his contemporaries. These findings will prompt a new discussion on the relationship between both participants of the communication - Leopold I and Johann Adolf of Schwarzenberg.

Leopold I would often discuss activities of imperial advisory bodies on the pages of his letters. For this reason the next part of the introductory study will focus on the political and admistrative activities of Johann Adolf of Schwarzenberg in the Privy Council and the Privy Conference and on their evaluation. ${ }^{60}$ However, it is not possible to describe them just on the basis of the preserved letters, as they often provide just snippets of information related to the meetings of these advisory bodies. It is, however, quite difficult to put them in any particular context. For this reason it is necessary to investigate also the private notes of Prince of Schwarzenberg concerning the meetings and negotiations of this advisory body and his short diaries from 1667 to $1668,1674-1675$ and 1681 . He described here his personal impressions from the Privy Conference, and provided an insider's view of its

57 P. MAŤA, Leopold I. a posledni Slavata, p. 249, footnote 18.

58 Moravský zemský archiv [Moravian Land Archives] Brno, G 140 - Rodinný archiv Ditrichštejnů [Dietrichstein Family Archives], Nr. 77, box 23, Nr. 85, box 26, Nr. 319-335, boxes 106-120, Nr. 1990, box 501; M. Dvǒ̌́́ (ed.), Briefe Kaiser Leopold I.

59 Carlo Guasti (ed.), Saggio di carteggi diplomatici del conte Lorenzo Magalotti dalla legazione a Vienna (1675-1678), Giornale Storico degli Archivi Toscani 4, 1860, pp. 137-164, 238-246, 318-341; Karl Gustav Helbig (ed.), Esaias Pufendorfs, königl. schwedischen Gesandten in Wien, Bericht über Kaiser Leopold, seinen Hof und die österreichische Politik 1671-1674, Leipzig 1862; Joseph Fiedler (ed.), Die Relationen der Botschafter Venedigs über Deutschland und Österreich im 17. Jahrbundert I-II, Wien 1866-1867; Alfred Francis Pribram (ed.), Aus dem Berichte eines Französen über den Wiener Hof in den Jahren 1671 und 1672, Mitteilungen des Instituts für Österreichische Geschichtsforschung 12, 1891, pp. 270-296; IDEm (ed.), Venetianische Depeschen vom Kaiserhofe (Dispacci di Germania) I. Band 1657, April-1661, Juli, Wien 1901; Artur Levinson (ed.), Nuntiaturberichte vom Kaiserbofe Leopolds I. (1657, Februar bis 1669, Dezember) I-II, Wien 1913; Oswald Reduich, Das Tagebuch Esaias Pufendorfs, schwedischen Residenten am Kaiserhofe von 1671 bis 1674, Mitteilungen des Instituts für Österreichische Geschichtsforschung 37, 1917, pp. 541-597; Geza von ANTAL - Jan C. H. de Pater (edd.), Weensche Gezantschapsberichten van 1670 tot 1720. Eerste deel, 1670-1697 I,'s-Gravenhage 1929. The editor will draw not only on published sources, but also on the results of his own previous research he had carried out in Archivio Segreto Vaticano, Biblioteca Apostolica Vaticana, Archivio Storico Famiglia Odescalchi and in several Czech and Austrian archives and libraries.

Cf. H. F. Schwarz, The Imperial Privy Council; S. Sienell, Die Geheime Konferenz. 
meetings. ${ }^{61}$ In addition to that, we will also draw on the minutes of the meetings of the Privy Conference, which are deposited in the Österreichisches Staatsarchiv, Wien, Haus-, Hof- und Staatsarchiv, Geheime österreichische Staatsregistratur and a part of it in Moravský zemský archiv [Moravian Land Archives] Brno, Rodinný archiv Ditrichštejnů [Dietrichstein Family Archives], in the estate of Ferdinand Josef of Dietrichstein (it contains many handwritten notes and other documents from the meetings). ${ }^{62}$

The edition of the private correspondence between Emperor Leopold I and Johann Adolf of Schwarzenberg will provide basis for a better understanding of the power structures at the courts in the Early Modern Age, their impact on the career of noblemen and their positions in the eyes of the sovereign. This topic belongs to the fundamental issues of the current research in royal courts in Europe. ${ }^{63}$ Furthermore, we will enquire about the various aspects of the intellectual world Habsburg emperors, in particular of Leopold I, about the daily life at the court in Vienna. We will be interested also in the attitudes and opinions of Johann Adolf of Schwarzenberg and other members of the imperial advisory bodies on the house affairs and foreign policy of the Habsburg monarchy in second half of the seventeenth century. ${ }^{64}$

The edition of the correspondence between Leopold I and Johann Adolf of Schwarzenberg from 1662 to 1683 will provide a transcription of the text of the letters. The transcription will follow the guidelines for editions of manuscript documents from the Early Modern Age, as suggested in the manual by Ivo Štovíček (published in Prague in 2002). ${ }^{65}$

61 Státní oblastní archiv [State Regional Archives] Třeboň, oddělení [Satellite Office] Český Krumlov, Rodinný archiv Schwarzenberků [Schwarzenberg Family Archives], file 365. See also Jean BÉrENGer, Deník Jana Adolfa ze Schwarzenberku, in: V. Bůžek (ed.), Šlechta raného novověku pohledem českých, francouzských a španělských historiků, pp. 41-57; R. SмíšEk, Císařský dvưr v polovině 17. století, pp. 263-314.

62 Moravský zemský archiv [Moravian Land Archives] Brno, G 140 - Rodinný archiv Ditrichštejnů [Dietrichstein Family Archives], Nr. 319-335, cart. 106-120.

63 Jeroen Duindam - Tülay Artan - Metin Kunt (edd.), Royal Courts in Dynastic States and Empires: A Global Perspective, Leiden-Boston 2011; Jeroen Duindam - Sabine Dabringhaus (edd.), The Dynastic Centre and the Provinces: Agents E Interactions, Leiden-Boston 2014; Jeroen Duindam, Dynasties: A Global History of Power 1300-1800, Cambridge 2016; Dries Raeymaekers - Sebastiaan Derks (edd.), The Key to Power? The Culture of Access in Princely Courts, 1400-1750, Leiden-Boston 2016; Ruben González Cuerva - Alexander Koller (edd.), A Europe of Courts, a Europe of Factions: Political Groups at Early Modern Centres of Power (1550-1700), Leiden-Boston 2017; Maaike van Berkel - Jeroen Duindam (edd.), Prince, Pen, and Sword: Eurasian Perspectives, Leiden-Boston 2018.

64 J. Duindam, Vienna and Versailles; Mark Hengerer, Access at the Court of the Austrian Habsburg Dynasty (Mid-Sixteenth to Mid-Eighteenth Century): A Highway from Presence to Politics, in: D. Raeymaekers - S. Derks (edd.), The Key to Power, pp. 124-152.

65 Ivan ŠŤOvíčEK a kol., Zásady vydáváni novovékých historických pramenů z obdobi od poćátku 16. století do současnosti. Př́prava védeckých edic dokumentủ ze 16.-20. stoleti pro potreby historiografie, Praha 2002. 
These guidelines do not represent a binding rule but they often help in solving editorial problems. They should help researchers whenever they encounter problems during their editorial work. In this context the editors will work with manuscript sources. The text of the handwritten document will be prepared for the edition in its entirety, with the greatest respect to the original textual structure. The internal arrangement of the letters had been determined by the character of the document. For this reason the topical and chronological layout and structuring of the transcribed text will follow consistently the original document. In doing so, we have to consider the unique character of the manuscript which requires a specific paleographical and linguistic approach. The main aim of the edition is to retain the original phonetic features of the text and all the means of expression with the help of modern graphical signs. ${ }^{66}$ The applied guidelines will respect the scholarly focus and principles of the series Prameny kéeským déjinám 16.-18. století (Documenta res gestas Bohemicas saeculorum XVI.-XVIII. illustrantia) where the edition will be published. The volume will follow up on previous editions of German, French and Latin documents that had appeared in this series. ${ }^{67}$ This series has been published by the Institute of History of the Academy of Sciences of the Czech Republic and the Institute of History of the Faculty of Arts of the University of South Bohemia in České Budějovice.

All the letters will be provided with a short summary (i.e. regesta). An important feature of this edition will be the numerous footnotes which shall provide information about people and places which Leopold I mentioned on the pages of his correspondence. The index of persons will add some more information about the identification of persons mentioned in the edited text. An important part of the edition will be commentaries on historical events and relations between the noblemen mentioned in the letters. The forthcoming edition will also have a bibliography of secondary works, a list of abbreviations, plus an index of persons, places and subjects. ${ }^{68}$ The whole edition and the introduction will be published in German because it discusses issues of general interest which may address even the international expert community.

66 Tomáš St ERneck, K problémům edičního zprístupñování raně novověkých pisemných pramenů (s di̊razem na materiál diplomatického charakteru), in: Pavel Otmar Krafl (ed.), Editorství a edice středověkých pramenů diplomatické povahy na úsvitu 21. století. Směry - tendence - proměny, Praha 2016, pp. 205-212. Cf. Oskar Reichmann, Zur Edition frühneuhochdeutscher Texte, Zeitschrift für deutsche Philologie 97, 1978, pp. 337-361; Walter Heinemeyer (ed.), Richtlinien für die Edition landesgeschichtlicher Quellen, Marburg-Hannover 2000.

67 Miroslava Durajová - Rostislav Sмíše (edd.), Hieronymus der Ältere Schlick: Das Tagebuch. Eine Selbstdarstellung aus den Jahren 1580-1582, České Budějovice 2008 (= Prameny k českým dějinám 16.-18. století. Řada B, svazek 2); Václav Вок - Anna Kuвíкová (edd.), Bericht über die Reise Johann Christians und Johann Seyfrieds von Eggenberg durch die Länder Mittel-, West- und Südeuropas in den Jahren 1660-1663. Eine kommentierte Edition, České Budějovice 2012 (= Prameny k českým dějinám 16.-18. století. Řada B, svazek 4); R. SмíšEx (ed.), Das Tagebuch Ferdinands zu Schwarzenberg.

Pavel VAšák, Textologie. Teorie a edični praxe, Praha 1993, pp. 120-121. 


\section{Rostislav Smíšek}

\section{The Correspondence between Emperor Leopold I and Johann Adolf of Schwarzenberg 1662-1683. Outline of an Edition Project (Abstract)}

The present study outlines the basic theses of an edition project. The main aim of the project is to publish about 150 handwritten letters that were sent between 1662 and 1683 by Emperor Leopold I. to Johann Adolf of Schwarzenberg, as a member of the Privy Council and later also as the President of the Imperial Privy Council. The letters reveal interesting new facts about the Emperor's intellectual world and his personality. Furthermore, the letters also discuss his advisory bodies (e. g. the Privy Council and Privy Conference). Many letters reflect the structure of the decision-making processes within these advisory bodies, opinions on appointments to particular offices, the central administrative authorities, and the relationship between the various administrative bodies and particular noblemen or individuals of low birth.

KEY WORDS:

$17^{\text {th }}$ century; House of Habsburg; critical edition; correspondence; Leopold I; Johann Adolf of Schwarzenberg 